\section{Views on Asian ESL learners' oral output and how drama-based cultural adjustment can help}

\author{
Gill, Chamkaur $\square$ \\ Bond University, Australia (cgill@bond.edu.au)
}

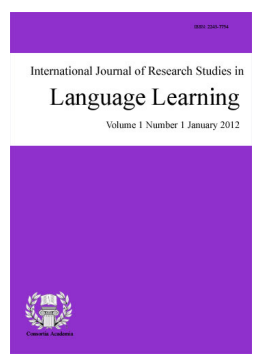

ISSN: 2243-7754

Accepted: 30 September 2017 Online ISSN: 2243-7762

\title{
Abstract
}

This discussion paper refers to the views of various authors regarding specific target language (TL) oral output issues and discusses problems faced by Asian learners of English-as-a-Second-Language (ESL), focusing on their ineffective verbal and non-verbal communication skills in an English language setting like Australia. An attempt is made to show that these problems can result in their avoiding extensive oral output in English for fear of being embarrassed. It suggests that drama-based cultural adjustment is a potential means of addressing these issues and problems. The paper proposes that, by incorporating elements of the host nation's culture in drama-based TL speech activities, the teacher can make lessons more interesting, thereby potentially increasing the learners' motivation to produce increased speech which, in turn, provides valuable practice which can lead to eventual improvement.

Keywords: oral English; Asian learners' problems; Australian English; drama; culture immersion 


\section{Views on Asian ESL learners' Oral output and how drama-based cultural adjustment can help}

\section{Introduction}

Coming from countries that exemplify relational behavior (Goh, 1996) whereby the group is more relevant than the individual and personal risk-taking is not the norm, Asian English-as-a-Second-Language (ESL) students generally tend to possess certain traits that can hinder their participation in speaking activities in class. These traits are both verbal and non-verbal in nature (Gill, 2004). This paper will focus on the quality of their speech, their body language and their voice-projection. These three factors could be restrictive in an environment where speech interaction tends to be robust, loud and animated, as is the case in Australia. Asian students are reluctant to participate in formal situations like classroom discussions for fear of being embarrassed (Gill, 2004). Trying to sound and behave like native speakers might make them nervous because (a) they are afraid of making errors and (b) they feel a sense of discomfort arising from having to participate in a culturally unfamiliar setting during formal target language (TL) speaking activities. Coming to terms with the demands of the TL and its associated cultural elements can play an important role in encouraging them to become more involved. Greater interaction is crucial if they are to increase their oral output and, in time, become better TL speakers.

Scarino and Liddicoat (2009) define culture as “... a framework in which people live their lives and communicate shared meanings with each other." (p. 19) and see a fundamental relationship between language and culture. The value of being part of such a framework in an English-speaking nation like Australia is of relevance to Asian students. While living their personal lives, they have to fit in with the English language surroundings. One of the ways of gradually fitting in is through finding the motivation to participate effectively in oral interaction in English. Assuming that very few Asian learners, if any, are self-motivating, encouraging them to speak becomes the responsibility of the teacher. The teacher can motivate them by stimulating their interest in the culture of the TL through exposure to, and immersion in, host-country-specific situations and identities. If they like what they experience, they may eventually communicate orally in the TL more regularly. This can be established through drama. Drama allows participants to step out of their own personalities and take on those of others in pretend scenarios. Actors, in the words of Stern (1980), "enter their characters' consciousness by temporarily giving up their own identity to take on a new dimension" (p. 81). Target language learners can benefit from such 'identity-shifts' because each new dimension incorporates immersion in the culture of the language they are learning in a relaxed and non-threatening way, a process during which they, consciously, subconsciously or unconsciously, may be able to absorb the language of that culture over time.

\section{Oral communication issues}

\subsection{Speech}

Asian learners of English, like those from Chinese-speaking backgrounds, often use imperfect pronunciation and intonation patterns (Gan, 2012; Zhang \& Yin, 2009) and this, according to Celce-Murcia and Olshtain (2001), can lead to miscommunication and misunderstanding. This is a conundrum that is probably due to the fact that "English and Chinese are two typologically distant languages" (Chan \& Li, 2000, p. 67). For example, Chinese students have problems with syllable lengths, resulting in words like 'dark', 'caught' and 'reach' sounding like 'duck', 'cot' and 'rich' (Gill, 2004). They, especially Cantonese speakers, also face hurdles when dealing with the rhythm patterns, strong and weak forms, and linkage structures of English (Chan \& Li, 2000). In addition, there are issues related to accents that can cause native-speakers to exhibit negative reactions like distaste (Fraser \& Kelly, 2012). When learners experience such reactions, it is highly likely that they will be nervous, uncertain, and even fearful during subsequent oral encounters with native speakers. Unfortunately, this 
could mean missing out on the variety of opportunities available for them to practice their speech with classmates and the wider community. It probably does not take too many repeats of such stressful situations for the learner to take measures to avoid them as often as possible.

As Gilbert (2005) puts it, "A few humiliating experiences ... may make learners so discouraged that they give up trying" ( $\mathrm{p}$. viii), thus rendering the job of teaching them a difficult one. A teacher can help reduce the stress by creating imaginary situations that simulate authentic TL cultural situations in psychologically undemanding ways involving a variety of interactions in a safe and enjoyable environment. Replacing stress arising from the fear of making mistakes with relaxed, learner-centered oral output could, according to Klinger (1999), encourage learners to take risks with the language and produce increasingly spontaneous speech resulting in successful communicative oral interaction. By becoming more participative and physically expressive, learners have opportunities to improve their prosody and pronunciation.

\subsection{Kinesics}

Kinesics, or using the body to communicate, is an important aspect of cultural identification. There are many Asians, among other nationalities, whose cultural upbringing requires them to avoid what they perceive as excessive eye contact (Samovar, Porter, \& McDaniel, 2009; Wolfe, 2017). To do so would be tantamount to disrespect. In addition, Asian ESL learners tend to be less animated and physically expressive than their native-speaker counterparts (Kleinsmith, De Silva, \& Bianchi-Berthouze, 2006). Beamer and Varner (2008) mention East Asians as displaying subdued arm movements and facial and postural demonstrations. The uncertainty and discomfort associated with having to use more robust body language might lead them to avoid participating in TL speaking activities, both in class and in the wider community, thus depriving themselves of additional opportunities to develop their oral skills in the language. Drama helps overcome this by immersing participants in roles and identities associated with the TL. It allows them to "test boundaries and cultural sensitivities as well as their linguistic progress in the target language" (Brash \& Warnecke, 2009, p. 102). By regularly inhabiting make-believe personalities of native English language speakers in experiential activities, they find themselves getting progressively more comfortable with more assertive body language (Gill, 2013). Regular immersion in simulated scenarios involving animated body language may, in time, help them self-regulate their less-inhibited gestures and facial expressions.

\subsection{Voice-projection}

Voice-projection is another aspect of play-acting which students from cultures where it is inappropriate to talk loudly can benefit from. For example, Filipinos, Thais and Japanese view soft voices as a sign of politeness and good upbringing (Samovar, Porter, \& McDaniel, 2009). Loud voices, as is sometimes the case when people in some European countries, the US and Australia communicate with each other, can be misinterpreted as indications of anger or rudeness. Goh (1996) states that to, people of Chinese backgrounds, a “... low tone of voice is preferred ..." (p. 111) in formal situations.

Asian students' participation in discussions is generally limited and when they do speak, their voices tend to be low and their demeanor conciliatory, as opposed to native speakers who have strong voices and who are not averse to interjections during discussions (Gill, 2004). Learners from Eastern cultural conditioning might feel overwhelmed by volume and therefore try to avoid oral interaction. Here too, by giving them the sanctuary of 'masks', teachers allow them to take on more robust identities that, in turn, can help reduce their anxiety. A diminished-anxiety environment could aid in lowering the affective filter, thereby encouraging risk-taking and creating effective learning conditions. The learners can take on various identities in skits and improvisations in a relaxed, fun-filled environment, without the threat of being judged by members of the wider community. Activities in class designed to typify what goes on in the native-speakers' world can help them function more positively outside the classroom. 


\section{Fitting in}

Boudreault (2010) states that, because we wish to be viewed by society in certain ways, we 'act' in the presence of others in order to achieve this objective, which is normally aligned with acceptance by society, not to mention acquiring an improved status. Ogbu (2004), in a paper on African-American identity in the United States, states that minorities "behave and talk like dominant group members in order to achieve self-betterment in situations controlled by members of the dominant group" (p. 6). In a similar fashion, migrants to a country with a different or dominant language and culture are likely to experience some form of identity-change over a period of time. In addition to having to cope with changed circumstances in which they experience difficulties associated with isolation, loneliness and settling in (Choudry, 2001), there are challenges that include aspects of the new culture that are difficult to relate to and the pressure of learning a new language (Hoang, 2008). How successfully they fit into their adopted environment relies heavily on how willing they are to accept their new identities.

Asian ESL students in Australia experience similar hurdles, albeit in an abbreviated fashion. They often have difficulty expressing themselves clearly and fluently when speaking (Gan, 2012; Huang, 2005; Liu \& Jackson, 2008; Sawir, 2005; Zhang \& Mi, 2009) and have difficulty matching the native-speaker counterparts in relation to voice, physical expression and confidence when speaking in English (Gill, 2004). Their limited vocabulary and grammar problems (Gan, 2012) may embarrass them and the fear of losing face could dissuade them from taking risks with the language. They can become inhibited, reticent and less inclined to speak due to the fear of rejection and low self-esteem (Stern, 1980) and also because of social anxiety (Schneier \& Welkowitz, 1996). Their stay away from home may span only the length of their studies, but the psychological pressure of learning to speak in English as they adjust to a new environment can be demanding. The faster their oral English skills improve, the quicker their adjustment to the host-nation's social and cultural setting. This can be achieved by interacting with English language speakers who are all around them. However, it has been observed that they prefer to keep the company of those of a similar culture to them (Xiao \& Petraki, 2007) with minimal oral interaction with native speakers.

There are learning opportunities in situations where TL learners interact with native speakers (Segalowitz \& Freed, 2004) but because there is limited contact between both parties, these valuable opportunities go to waste. While they are not expected to absorb Australian culture totally, it will help their cause if there is occasional adjustment to accommodate the host nation's culture. Learning English through drama contains elements of such immersion. Norton Pierce (1995) suggests that teachers can help learners improve by “... collapsing the boundaries between their classrooms and their communities." (p. 26). Role-play and improvisations, for example, can replicate such social networking, thus creating a bridge between the classroom and the culture outside it. Learners regularly exposed to such methodology may eventually become sufficiently comfortable with the TL and be progressively more capable of interacting confidently with native-speakers, without losing their own identities. How soon learners develop to the point where they have comfortably adjusted to the TL culture and are able to speak sufficiently fluently and clearly for native-speakers to understand them depends on how open they are to adjusting to the culture and the language. Such adjustment could be represented in the form of a simple diagram, as below. The lighter circle represents the learner while the darker part represents the increasing adjustment. The former is larger to indicate that the learner still retains pre-existing personal characteristics linked to her or his own culture and language.

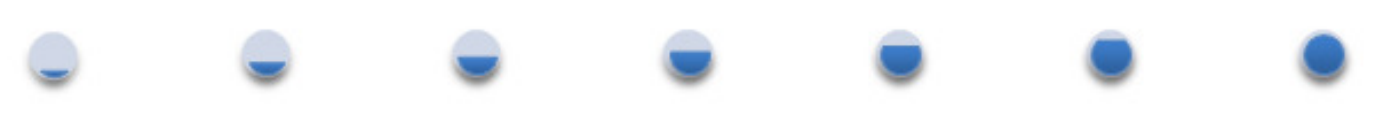

Figure 1. Stages of culture/language adjustment by target-language learners 
Views on Asian ESL learners' Oral output and how drama-based cultural adjustment can help

Participating in activities that remove them from their own familiar groundings and domains and place them in relatively untested situations and identities that reflect the culture of the English language gives learners "the opportunity to develop their emotional range by playing roles unfamiliar to them and outside their own experience" (Davies, 1990, p. 95). They submerge themselves in play-acting situations that give them access to roles and situations associated with the culture of the language they are learning. Their end-product skills in grammar and vocabulary may not match those of native-speakers, but evidence indicates that their fluency and ability to communicate in the target language improves with immersion (Lyster, 2008). As their confidence increases, there is the likelihood of increasingly fluent and clear speech, improved kinesics and a stronger voice.

\section{Drama and identity}

One of the key strengths of drama in a language-learning environment is that it provides "... the requisite motivational basis for purposeful communication" (Lyster, 2008, p. 5). By infusing cultural elements in drama-based lessons, TL teachers can help learners view class sessions as learning about something new and interesting and not just about language, thus creating an environment that can result in meaningful communication. Focus leans more towards the message than the code (Stern, 1992). New experiences can stimulate the sort of curiosity that enhances learning (Gruber, Gelman, \& Ranganath, 2014), thereby leading to greater motivation and receptivity (Barkhuizen, 1998). Motivation generates productivity (Ryan and Deci, 2000). It propels learners into situations where they are able to speak uninhibitedly in the target language as they interact freely with their classmates and the teacher through their acting roles. Regular exposure to elements of the TL culture in an enjoyable, anxiety-free backdrop can play a major role in upgrading their oral abilities. In the words of Stern (1980),

\section{A play allows learners to participate in a new culture, helping them develop sensitivity as to how speakers of the target language interact with each other. It familiarizes them with the cultural appropriateness of words and expressions to specific settings and social situations. Ideally, this integrative experience should motivate learners to want to achieve a higher degree of language proficiency (p. 79).}

An ESL course that incorporates the complexities of the new locale in which learners find themselves can help ease their transition into the unfamiliar environment. So, for instance, an Australian ESL course could encompass subject-matter that deals with 'Australian-isms', including identities, customs, special events and the use of Australian slang. An example of a special event is Melbourne Cup Day. Most Australians look forward to it, not just because it is a major horse-race event, but also because women can wear their most flamboyant hats while men dress in tuxedos, all the while maintaining an informal, carnival-like atmosphere that sometimes borders on the irreverent. An ESL instructor can take the subject-matter to another level by dealing with it experientially such that learners act out scenes associated with the event. The inherent novelty of such an approach may create the sort of excitement conducive to learning. Bunzeck and Düzel (2006) found that new experiences result in greater activity in the part of the brain responsible for motivation. By getting learners interested in specific situations related to the event, teachers can give them impetus to want to find out more. Such situational interest has the potential to lead to long-term interest (Palmer, 2009).

While touting the value of drama as a learning tool, it has to be admitted that it can result in anxiety and tension but a good teacher with the ability to create a fun-filled, make-believe environment can use such tension to promote learning. Tseng (2002) refers to learning that occurs as a result of facilitative tension that arises from cultural differences, and mentions process-drama as a way of achieving this. Cultural taboos appear to matter less when students pretend to be foreigners, saying and doing things they shy away from in real life. Hudson and Bruckman (2002) contend that language output in environments with reduced inhibition can result in more effective learning. Uncomfortable situations become less so within the safety of fiction (Brash \& Warnecke, 2009). 
Drama, according to Boudreault (2010), helps us improve our TL skills and achieve our target identities. My students are often asked to act as Australian hotel receptionists, delivery boys, nurses, farmers, sales-people, beach-goers, and so on, with the aim of letting them practice with the jargon and mannerisms of these roles. No demands are placed on them to stick to rigid ways of playing these roles. All that is required of them is to stay relaxed and enjoy taking on Australian alter egos for the duration of their performances. Their comfort levels go up when communication flows easily and they become less nervous about interacting in English. In the process of immersing themselves in their roles, they are encouraged to use Australian lingo like 'arvo' (afternoon), "g'day" (good day), "how ya goin'?" (how are you?), "hooroo" (see you later), "cheers" (thanks) and so on. The more they get used to such slang, the less perplexing Australian English and culture is to them. Here are two examples of the value of being familiar with local speech: A Malaysian student at a bus-stop was asked "how ya goin'?" by her Australian friend and she mistakenly replied 'by bus" while a Kuwaiti student buying a burger at a fast-food restaurant misheard the cashier's "Cheers" as "Cheese" and, thinking that the former was inquiring as to whether he needed cheese with the burger, replied "No, thank you." It is possible to take such examples and incorporate them in drama-based cultural activities in an ESL class to enhance students' learning of both English and culture.

\section{Conclusion}

In conclusion, drama creates an atmosphere conducive to learning through imagination, with learners experimenting with, and internalizing crucial aspects of, the host-nation culture, the target identity and English. An experiment with drama as an ESL learning tool in the field of oral output (Gill, 2013) found that subjects exposed to drama over a 12-week period used more spoken English, produced longer sentences, used greater eye contact and were less self-conscious about their loud, excited voices and animated body language.

There are hurdles associated with ESL oral interaction that my learners accept they have to negotiate. While they never cleanly jump over all of them, sometimes clipping them and at other times knocking them over altogether, they inevitably reach the finish line at the end of the activity. From my observations, the more they participate in such activities, the more comfortable they get and the less taxing the race. I try to use drama to help them develop an affinity for the ESL culture, hoping it will make them start liking English and, in the process, develop their speaking abilities in the TL. Indeed, I have noticed substantially greater use of English amongst those who have integrated with Australian culture than those who have not. It is this latter group which could benefit from cultural immersion through drama.

Acknowledgement: This paper is a modified version of a paper titled "Immersion in ESL culture: Oral output through acting" that I presented at the $6^{\text {th }}$ International Language Learning Conference held in Penang Malaysia, 2-4 November 2015.

\section{References}

Barkhuizen, G. P. (1998). Discovering learners' perceptions of ESL classroom teaching/learning activities in a South African context. TESOL Quarterly, 31(1), 85-107. http://dx.doi.org/10.2307/3587903

Beamer, L., \& Varner, I. (2008). Intercultural communication in the workplace (4th ed.). Boston; London: McGraw-Hill Irwin.

Boudreault, C. (2010). The benefits of using drama in the ESL/EFL classroom. The Internet TESL Journal, 16(1). Retrieved from http://iteslj.org/Articles/Boudreault-Drama.html

Brash, B., \& Warnecke, S. (2009). Shedding the ego: Drama-based role-play and identity in distance language tuition. Language Learning Journal, 37(1), 99-109. http://dx.doi.org/10.1080/09571730902717661

Bunzek, N., \& Düzel, E. (2006). Absolute coding of stimulus novelty in the human substantia nigra/VTA. Neuron, 51, 369-379. http://dx.doi.org/10.1016/j.neuron.2006.06.021

Celce-Murcia, M., \& Olshtain, E. (2001). Discourse and context in language teaching: A guide for teachers. 
Views on Asian ESL learners' Oral output and how drama-based cultural adjustment can help

Cambridge University Press.

Chan, A. Y. W., \& Li, C. S. (2000). English and Cantonese phonology in contrast: Explaining Cantonese ESL learners' English pronunciation problems. Language, Culture and Curriculum, 13(1), 67-85. http://dx.doi.org/10.1080/07908310008666590

Choudry, U. K. (2001). Uprooting and resettlement experiences of South Asian immigrant women [Electronic version]. Western Journal of Nursing Research, 23(4), 376-393. https://doi.org/10.1177/019394590102300405

Davies, P. (1990). The use of drama in English language teaching. TESL Canada Journal, 8(1), 87-99. https://doi.org/10.18806/tesl.v8i1.581

Fraser, C., \& Kelly, B. F. (2012). Listening between the lines: Social assumptions around foreign accents. Australian Review of Applied Linguistics, 35(1), 74-93. https://doi.org/10.1075/aral.35.1.04fra

Gan, Z. (2012). Understanding L2 speaking problems: Implications for ESL curriculum development in a teacher training institution in Hong Kong. Australian Journal of Teacher Education, 37(1), 42-59. http://dx.doi.org/10.14221/ajte.2012v37n1.4

Gilbert, J. B. (2005). Clear speech: Pronunciation and listening comprehension in North America: New York, NY. Cambridge University Press.

Gill, C. (2004). Drama as a means of improving the advocacy skills of non-English-speaking-background students. Proceedings of the $9^{\text {th }}$ National Community Languages and ESOL (English to Speakers of Other Languages) Conference (CLESOL 2004). Christchurch, New Zealand. Retrieved from http://epublications.bond.edu.au/cgi/viewcontent.cgi?article=1001\&context=chamkaur_gill

Gill, C. (2013). Enhancing the English-language oral skills of international students through drama. English Language Teaching, 6(4), 29-41. http://dx.doi.org/10.5539/elt.v6n4p29

Goh, B. C. (1996). Negotiating with the Chinese. Aldershot, Hants: Dartmouth Publishing Company.

Gruber, M. J., Gelman, B. D., \& Ranganath, C. (2014). States of curiosity modulate hippocampus-dependent learning via the dopaminergic circuit. Neuron, 84, 486-496. http://dx.doi.org/10.1016/j.neuron.2014.08.060

Hoang, H. (2008). Language and cultural barriers of Asian migrants in accessing maternal care in Australia. The International Journal of language, society and culture, 26, 55-61. Retrieved from https://www.researchgate.net/publication/237821840_Language_and_Cultural_Barriers_of_Asian_migr ants_in_Accessing_Maternal_care_in_Australia

Huang, J. (2005). A diary study of difficulties and constraints in EFL learning. System, 33, 609-621. http://dx.doi.org/10.1016/j.system.2005.04.001

Hudson, J., \& Bruckman, A. (2002). Disinhibition in a CSCL environment. In the Proceedings of the conference on computer support for collaborative learning (pp. 629-630). Boulder CO. https://doi.org/10.3115/1658616.1658757

Kleinsmith, A., De Silva, P. R., \& Bianchi-Berthouze, N. (2006). Cross-cultural differences in recognizing affect from body posture. Interacting with Computers, 18(6), 1371-1389. http://dx.doi.org/10.1016/j.intcom.2006.04.003

Klinger, W. (1999). Unrehearsed speaking activities for language learning. Academic Reports of the University Center for Intercultural Education, The University of Shiga Prefecture, No. 4, Hikone, Japan.

Liu, M., \& Jackson, J. (2008). An exploration of Chinese EFL learners' unwillingness to communicate and foreign language anxiety. The Modern Language Journal, 92, 71-86. http://dx.doi.org/10.1111/j.1540-4781.2008.00687.x

Lyster, R. (2008). Evolving perspectives on learning French as a second language through immersion. In D. Ayoun (Ed.), Studies in French applied linguistics (pp 3-36). Amsterdam: John Benjamins. https://doi.org/10.1075/11lt.21.05lys

Norton Pierce, B. (1995). Social identity, investment, and language learning. TESOL Quarterly, 29(1), 9-31. Retrieved from http://faculty.educ.ubc.ca/norton/Norton\%201995\%20p.pdf https://doi.org/10.2307/3587803

Ogbu, J. U. (2004). Collective identity and the burden of 'acting white' in black history, community, and 
Gill, C.

education. The Urban Review, 36(1), 1-35. https://doi.org/10.1023/B:URRE.0000042734.83194.f6

Palmer, D. H. (2009). Student interest generated during an inquiry skills lesson. Journal of Research in Science Teaching, 46(2), 147-165. http://dx.doi.org/10.1002/tea.20263

Ryan, R. M., \& Deci, E. L. (2000). Self-determination theory and the facilitation of intrinsic motivation, social development and well-being. American Psychologist. http://dx.doi.org/10.1037/0003-066X.55.1.68

Samovar, L. A., Porter, R. E., \& McDaniel, E. R. (2009). Communication between cultures (7th ed.). Wadsworth, Cengage Learning, Boston, MA.

Sawir, E. (2005). Language difficulties of international students in Australia: The effects of prior learning experiences. International Educational Journal, 6(5), 567-580.

Scarino, A., \& Liddicoat, A. J. (2009). Teaching and learning languages: A guide. Melbourne: Department of Education, Employment and Workplace Relations, Commonwealth of Australia.

Schneier, F., \& Welkowitz, L. (1996). The hidden face of shyness. New York: Avon Brooks.

Segalowitz, N., \& Freed, B. F. (2004). Context, contact, and cognition in oral fluency acquisition: Learning Spanish in at home and study abroad contexts. Studies in Second Language Acquisition, 26(2), 173-199. http://dx.doi.org/10.1017/S0272263104262027

Stern, H. H. (1992). Issues and options in language teaching. Oxford: Oxford University Press.

Stern, S. L. (1980). Drama in second language learning from a psycholinguistic perspective. Language Learning, 30(1), 77-100. http://dx.doi.org/10.1111/j.1467-1770.1980.tb00152.x

Tseng, Y. (2002). A lesson in culture. ELT Journal, 56(1), 11-21. http://dx.doi.org/10.1093/elt/56.1.11

Wolfe, L. (2017) How eye contact can help you close the sale. Retrieved from http://womeninbusiness.about.com/od/businessetiquette/a/making-eye-contact.htm

Xiao, H., \& Petraki, E. (2007). An investigation of Chinese students' difficulties in intercultural communication and its role in ELT. Journal of Intercultural Communication, 13. Retrieved from http://www.immi.se/intercultural/nr13/petraki.htm

Zhang, F., \& Yin, P. (2009). A study of pronunciation problems of English learners in China. Asian Social Science, 5(6), 141-146. https://doi.org/10.5539/ass.v5n6p141

Zhang, Y., \& Mi, Y. (2009). Another look at the language difficulties of international students. Journal of Studies in International Education, 20(10), 1-18. 